Review article

\title{
Determinants of postmenopausal osteoporosis
}

\author{
Mária Šupínová ${ }^{1 *}$, Elena Janiczeková ${ }^{1}$, Júlia Jankovičová ${ }^{1,2}$, Jana Lauková ${ }^{1}$ \\ ${ }^{1}$ Slovak Medical University in Bratislava, Faculty of Health in Banská Bystrica, Banská Bystrica, Slovak Republic \\ 2 Slovak Medical University in Bratislava, Faculty of Nursing and Professional Health Studies, Bratislava, Slovak Republic
}

\begin{abstract}
Introduction: Osteoporosis is generally associated with menopause. Scientific research has shown the existence of several factors involved in decreasing bone density in post-menopausal women.

Goal: The aim of the review study is to map in detail the prevalence of osteoporosis in postmenopausal women in the context of postmenopausal age, postmenopausal duration, women's BMI and selected behavioural factors.

Methods: Relevant sources were selected in 2020 using search services and sources in electronic databases (PubMed, BioMed Central, Web of Science). The analytical review was performed using PRISMA and PICO tools.

Results and discussion: In analysing the available studies, we found that the most frequently observed significant findings showed a relationship between the prevalence of osteoporosis and age at menopause and the prevalence of osteoporosis and advancing age in postmenopause. Opinions differ on the influence of BMI as a protective or risk factor. Some behavioural factors that are preventable can have a significant effect on bone mineral density in postmenopausal women. The results of several studies suggest an association between the prevalence of osteoporosis and smoking and alcohol consumption.

Conclusions: Menopause is a critical period for bone health. The incidence of osteoporosis increases with increasing age of postmenopausal women. As part of prevention, it is recommended to have a suitable type of diet, exposure to sunlight, regular exercise and to stop smoking and drinking alcohol.
\end{abstract}

Keywords: Age; BMI; Diet; Menopause; Osteoporosis

\section{Introduction}

With the increased life expectancy of the world's population in recent decades, there has been growth in the incidence of illnesses of the most advanced ages, including osteoporosis (Cunha-Henriques et al., 2011). Its prevalence is most often associated with menopause (Török-Oancea and Bala, 2015). Menopause as a biological process occurs at the age of approximately 40 to 60 years (mean value 51 years). Menopause is defined as the permanent cessation of menstruation. The diagnosis is made retrospectively after menstruation has been absent for 12 months (Koothirezhi and Ranganathan, 2021; Moron et al., 2009). Menopausal age is important as a retrospective marker for ovarian senescence. An early menopausal age is associated with an increased risk of cardiovascular diseases and osteoporosis. A later menopausal age has been associated with an increased risk of breast cancer. Experts consider genetic factors to be the main source of age variation. Environmental factors explain only a small part of the variance (Kok et al., 2005; van Asselt et al., 2004; Voorhuis et al., 2010). According to Koothirezhi and Ranganathan (2021), health concerns among menopausal women are mainly related to vasomotor symptoms, urogenital atrophy, osteoporosis, cardiovascular disease, cancer, psychiatric symptoms, cognitive decline, and sexual problems. Menopause is a critical period for bone health, with rapid losses in bone mass and strength occurring in a 3-year window bracketing the date of the final menstrual period. Monitoring of bone density is important in predicting the onset of the rapid loss phase and in identifying the women who are most at risk of osteoporosis during menopause, as well as in assessing the effectiveness of osteoporosis treatment (Karlamangla et al., 2018).

According to Brown et al. (2009), osteoporosis is the most common cause of fractures. It is estimated that in the USA and the European Union around 30\% of women who have reached menopause are suffering from osteoporosis. In Asia, the overall prevalence of osteoporosis is higher than in the western countries (Török-Oancea and Bala, 2015). A low Body Mass Index (BMI) is a risk factor for bone loss (Aghaei et al., 2013). The protective effect of overweight on osteoporosis is not clear (Salamat et al., 2013; Schoenaker et al., 2014).

The described starting points provided the impetus for an analytical review that provides a systematic review of published studies on the topic. We mapped the key factors: osteoporosis, menopause, age of the woman, obesity, and smoking.

\footnotetext{
* Corresponding author: Mária Šupínová, Slovak Medical University in Bratislava, Faculty of Health in Banská Bystrica, Sládkovičova 21, 97401 Banská Bystrica, Slovak Republic; e-mail: maria.supinova@szu.sk http://doi.org/10.32725/kont.2021.045 


\section{Materials and methods}

The analytical review was performed using PRISMA and PICO tools. The present study is an evaluation of current theories on osteoporosis in postmenopausal women. Secondary analysis and detailed examination of relevant sources using the PubMed, BioMed Central and Web of Science electronic databases using certain keywords were used to determine the key terms. The keywords were osteoporosis, menopause, age and BMI, which have been extended to include the concepts of obesity and smoking. The operators defining the logical re- lationships between the individual keywords were "and/or". Empirical results, as well as theoretical knowledge identifying the degree of knowledge in relation to the studied variables in English, were searched for. Published studies for the last 10 years (from 2010 to 2020 inclusive) were analyzed. The second phase of the review included studies with the condition that free full texts were available. The analytical and research phase was conducted from May to November 2020. The search process is shown in the PRISMA literature review flow diagram (Fig. 1). After a thorough assessment by the authors, the analysis included the 5 most relevant studies, which most reflected the defined clinical issues (Table 1).
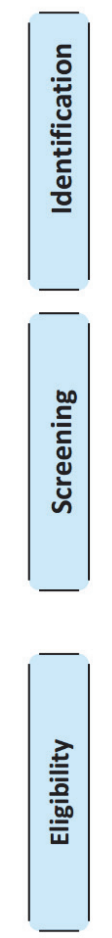

Records identified through database searching $(n=2881)$
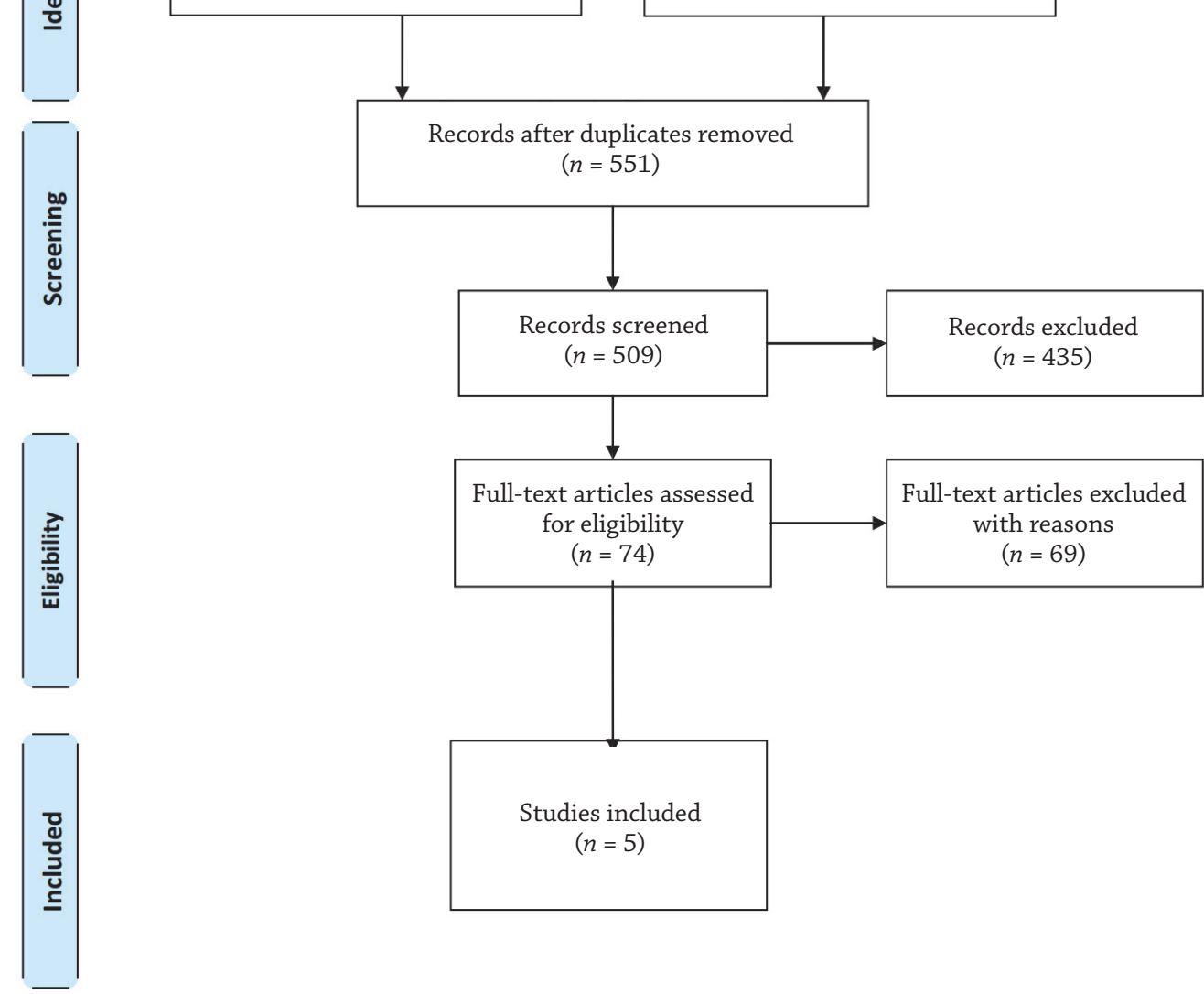

Fig. 1. PRISMA flow diagram for the selection of studies

The aim of the review study was to map in detail the prevalence of osteoporosis in postmenopausal/climacteric women in the context of age at menopause, duration of postmenopause/climacterium, women's BMI and selected behavioural factors, in available published outcomes.

The main clinical question was compiled using a standardized PICO format.

\section{Basic clinical question}

Is there a higher prevalence of osteoporosis in postmenopausal women with increasing age?
Specific clinical questions:

- Does age of onset of menopause affect the prevalence of osteoporosis in menopausal women?

- Does the increasing postmenopausal age of women affect the progression of osteoporosis?

- Does the weight and BMI of postmenopausal women affect the prevalence of osteoporosis?

- Do selected lifestyle-related behavioural factors affect the prevalence of osteoporosis in menopausal women? 
Table 1. Studies included in the analysis

\begin{tabular}{lll}
\hline Authors & Title of study & Database \\
\hline Agrawal and Verma (2013) & Cross sectional study of osteoporosis among women & $\begin{array}{l}\text { Association of breastfeeding and postmenopausal osteoporosis in Chinese women: a community- } \\
\text { based retrospective study }\end{array}$ \\
\hline Guiming et al. (2019) & $\begin{array}{l}\text { Prevalence of osteoporosis and related lifestyle and metabolic factors of postmenopausal women and } \\
\text { elderly men: A cross-sectional study in Gansu province, Northwestern of China }\end{array}$ \\
Tian et al. (2017) & $\begin{array}{l}\text { Body weight, BMI, and stature have a protective effect on bone mineral density in women with } \\
\text { postmenopausal vertebral osteoporosis, whereas greater age at menarche and years after menopause } \\
\text { have a negative effect }\end{array}$ & Factors associated with osteopenia and osteoporosis in women undergoing bone mineral density test \\
\hline Veiga Silva et al. (2015) & & WOS \\
\hline
\end{tabular}

\section{Results and discussion}

Osteoporosis, as a public health problem, is generally associated with menopause. It affects one out of three postmenopausal women (Rizzoli et al., 2014). A positive relationship of osteoporosis with older age of postmenopausal women is reported in the literature. With increasing age, the risk of other associated diseases increases, which can worsen the quality of life (Haluzikova, 2017). According to Cunha-Henriques et al. (2011), older women with osteoporosis may suffer from a deterioration in musculoskeletal status, which in the long term may result in limitations to their daily activities, as well as lumbar pain, an increase in the occurrence of falls, and a consequent increase in fracture risk. Scientific studies show that there are many factors associated with decreased bone mineral density and osteoporosis in postmenopausal women.
We analyzed in detail the available scientific studies (Table 2) focused on the prevalence and risks of postmenopausal osteoporosis.

The aim of the analysis was to determine how age, BMI values, duration of climacterium as well as selected lifestyle-related behavioural factors affect the progression of osteoporosis in menopausal women.

\section{Age at menopause - increasing postmenopausal age}

The results of the studies showed a very significant association between the incidence of osteopenia and osteoporosis and age, as well as the number of years after menopause (Demirbag et al., 2006). Hamdi Kara et al. (2008) also report increasing age (over 65 years) combined with illiteracy as risk factors for osteopenia and osteoporosis (2008). Baccaro et al. (2015) report a positive association between osteoporosis and age $>45$ years.

Table 2. Objectives and results of the studies

\begin{tabular}{|c|c|c|c|c|}
\hline Authors & Country of study & Type of study & Objective & Results \\
\hline $\begin{array}{l}\text { Agrawal and } \\
\text { Verma (2013) }\end{array}$ & Uttarakhand - India & $\begin{array}{l}\text { Cross-sectional } \\
\text { descriptive } \\
\text { study }\end{array}$ & $\begin{array}{l}\text { A study of the prevalence of osteopenia } \\
\text { and osteoporosis and their correlation } \\
\text { with epidemiological and socio- } \\
\text { behavioural factors in women over } 35 \\
\text { years of age }\end{array}$ & $\begin{array}{l}\text { The prevalence of osteopenia and } \\
\text { osteoporosis is related to age; number of } \\
\text { pregnancies; age at menopause; greater } \\
\text { weight; there was a positive correlation } \\
\text { with a physically active lifestyle }\end{array}$ \\
\hline $\begin{array}{l}\text { Guiming et al. } \\
\text { (2019) }\end{array}$ & $\begin{array}{l}\text { Tianjin Xiaobailou - } \\
\text { China }\end{array}$ & $\begin{array}{l}\text { Retrospective } \\
\text { cross-sectional } \\
\text { study }\end{array}$ & $\begin{array}{l}\text { To assess the effect of age, BMI, vitamin } \\
\text { D and calcium intake, history of smoking, } \\
\text { alcohol drinking and fractures, age at } \\
\text { menarche, age at menopause, number } \\
\text { of pregnancies, parity, diet and overall } \\
\text { duration of breastfeeding on the incidence } \\
\text { of osteoporosis in postmenopausal } \\
\text { women }\end{array}$ & $\begin{array}{l}\text { Breastfeeding is not associated with } \\
\text { postmenopausal osteoporosis; increasing } \\
\text { age, higher BMI and higher number } \\
\text { of pregnancies are associated with } \\
\text { an increased risk of postmenopausal } \\
\text { osteoporosis }\end{array}$ \\
\hline Tian et at. (2017) & Gansu - China & $\begin{array}{l}\text { Cross-sectional } \\
\text { study }\end{array}$ & $\begin{array}{l}\text { To examine the prevalence of osteoporosis } \\
\text { and the risks in postmenopausal women } \\
\text { and older men. }\end{array}$ & $\begin{array}{l}\text { The risk of osteoporosis is related to age } \\
\text { of onset of menopause, increasing age } \\
\text { in menopause, higher BMI and level of } \\
\text { education in postmenopausal women }\end{array}$ \\
\hline $\begin{array}{l}\text { Török-Oancea } \\
\text { and Bala (2015) }\end{array}$ & Timișoara - Romania & $\begin{array}{l}\text { Retrospective } \\
\text { cross-sectional } \\
\text { study }\end{array}$ & $\begin{array}{l}\text { To assess the effect of age, menarche } \\
\text { time, age at menopause, number of } \\
\text { reproductive years (reproductive period), } \\
\text { number of years after menopause, } \\
\text { body weight, figure and BMI on spinal } \\
\text { bone density (BMD) in women with } \\
\text { postmenopausal vertebral osteoporosis }\end{array}$ & $\begin{array}{l}\text { Weight and higher BMI have a protective } \\
\text { effect on bone density; increasing age, age } \\
\text { of onset of menopause, increasing number } \\
\text { of years after onset of menopause have a } \\
\text { negative effect on spinal density }\end{array}$ \\
\hline $\begin{array}{l}\text { Veiga Silva et al. } \\
\text { (2015) }\end{array}$ & South of Brazil & $\begin{array}{l}\text { Cross-sectional } \\
\text { study }\end{array}$ & $\begin{array}{l}\text { To determine the prevalence of } \\
\text { osteopenia and osteoporosis in a female } \\
\text { population in which bone mineral density } \\
\text { (BMD) was measured by dual energy X-ray } \\
\text { absorptiometry (DXA) at a specialized } \\
\text { clinic in southern Brazil }\end{array}$ & $\begin{array}{l}\text { The prevalence of osteopenia is higher } \\
\text { than the prevalence of osteoporosis; } \\
\text { aging and menopause are risk factors for } \\
\text { both groups; BMI above } 25 \text { and previous } \\
\text { hysterectomy are protective factors }\end{array}$ \\
\hline
\end{tabular}


The results of a retrospective study in Caucasian women with postmenopausal vertebral osteoporosis also showed a very significant relationship between the incidence of osteopenia and osteoporosis and age and number of years after menopause (Török-Oance and Bala, 2015).

A study conducted by Guiming et al. (2019) showed that the prevalence of postmenopausal osteoporosis in postmenopausal women with advanced age was significantly higher than in the lower age group. However, according to the authors, the age at the onset of menopause was not significant in the group without osteoporosis compared to the group with osteoporosis.

According to Tian et al. (2017), the risk of osteoporosis was significantly associated with menopause onset age and menopause duration. Menopause and age over 50 years were reported as risk factors for both osteopenia and osteoporosis in the results of a study by Veiga Silva et al. (2015). They report a linear increase in osteopenia and osteoporosis with advancing age of postmenopausal women. According to the results of their study, Agrawal and Verma (2013) showed that the statistical relationship between the prevalence of osteopenia and osteoporosis is significant in relation to the age of women, the number of pregnancies and the age of menopause. According to Binu et al. (2019), the number of years since menopause had an adverse effect on the skeleton.

\section{Weight and BMI}

Opinions differ on the influence of BMI as a protective or risk factor for the prevalence of osteoporosis. According to the results of some studies, weight, BMI and body shape have a protective effect on the spinal density of bone tissue (TörökOance and Bala, 2015). Also, according to Veiga Silva et al. (2015), postmenopausal women with a BMI above 25 had a statistically significantly lower incidence of osteopenia or osteoporosis. In contrast, according to Guiming et al. (2019), the prevalence of postmenopausal osteoporosis was significantly higher in postmenopausal women with higher BMI and higher number of pregnancies. Higher BMI as a risk factor for osteoporosis in postmenopausal women is reported by Tian et al. (2017) and Agrawal and Verma (2013).

\section{Behavioural factors}

Many preventable environmental risk factors can have significant effects on bone mineral density in postmenopausal women. The results of several studies suggest that smoking is an independent risk factor for osteoporosis in postmenopausal women (Bijelic et al., 2017; Rizzoli et al., 2014). Tian et al. (2017) report alcohol as a significant risk factor for osteopenia and osteoporosis in menopausal women.

The study by Kalem et al. (2017) found no significant differences between groups of postmenopausal women with osteoporosis due to smoking, coffee consumption and consumption of milk and dairy products. According to Guiming et al. (2019), diet was not significant in the group of postmenopausal women without osteoporosis compared to the group with osteoporosis.

Furthermore, the increased risk of postmenopausal osteoporosis was not significantly associated with a longer duration of breastfeeding lasting more than 24 months (Guiming et al., 2019).
It is important to understand the associated risk factors, clinical presentation, and the management of common menopausal symptoms in order to improve patient care and health outcomes for older female patients (Koothirezhi and Ranganathan, 2021).

\section{Prevention of osteoporosis}

The prevention and treatment of osteoporosis consists of non-pharmacological and pharmacological measures. According to Agrawal and Verma (2013), the benefits of the three components of non-pharmacological therapy are well established these include diet, exposure to sunlight, regular exercise and cessation of smoking and alcohol consumption. Healthy lifestyle (diet, exercise and sunlight exposure) can have a major positive impact on bone health. According to Török Oancea and Bala (2015), regular assessment of bone mineral density (BMD) is important because it may help in assessing the risk of osteoporosis and subsequent fractures. According to Rizzoli et al. (2014), it is possible to reduce the risk of osteoporosis by lifestyle modifications. These include adequate dietary intake of calcium, vitamins and proteins, regular exercise, reduction in alcohol intake and refraining from smoking. These public health measures are recommended for the general population because they are effective, safe and cost-effective. Therefore, there is an urgent need to raise public awareness of this. In the case of middle-aged and elderly people, early detection and treatment of osteoporosis with available substances can significantly reduce the risk of fractures and associated morbidity and mortality.

\section{Conclusions}

According to research, postmenopausal osteoporosis is a global public health problem. Analysis of the results of studies shows the relationship between the prevalence of osteoporosis or osteopenia and age at onset of menopause and increasing age in the postmenopausal period. The relationship between higher BMI as a protective factor in relation to the prevalence of osteoporosis is not clear. Therefore, it would be advisable to analyse the relationship of these variables to cultural and ethnic factors; we consider the absence of this in the present study to be a limiting factor. With regards to preventable behavioural factors, a higher prevalence of osteoporosis was found in postmenopausal women who smoked, and in association with higher alcohol consumption. The degree of prevalence of postmenopausal osteoporosis in relation to diet or consumption of dairy products (as a source of protein) has not been clearly demonstrated. Physical activity and exercise in postmenopausal women have been clearly confirmed as a protective factor.

Population studies are essential to identify risk factors for falls and fractures in different populations to help physicians providing care for postmenopausal women.

\section{Author contributors}

Concept and design (MŠ, EJ, JL, JJ), data analysis and interpretation (MŠ, EJ, JL, JJ), draft manuscript (MŠ), critical revision of manuscript (MŠ, EJ, JL, JJ), final article (MŠ).

\section{Ethical aspects and conflict of interests}

The authors have no conflict of interests to declare. 


\section{Determinanty postmenopauzálnej osteoporózy}

\section{Súhrn}

Úvod: Osteoporóza je všeobecne spájaná s menopauzou. Vedecké štúdie preukázali existenciu viacerých faktorov podiel'ajúcich sa na znižovaní kostnej denzity u žien v postmenopauze.

Ciel': Ciel'om prehl'adovej štúdie je podrobne zmapovat' prevalenciu osteoporózy u žien v postmenopauze v kontexte veku v menopauze, dĺžky trvania postmenopauzy, BMI ženy a vybratých behaviorálnych faktorov.

Metódy: Výber relevantných zdrojov bol realizovaný v roku 2020 pomocou vyhl'adávacích služieb a zdrojov v elektronických databázach (PubMed, BioMed Central, Web of Science). Analytická prehl'adová štúdia bola spracovaná s využitím techniky PRISMA a PICO.

Výsledky a diskusia: Analýzou dostupných výskumných štúdií sme zistili, že najčastejšie pozorované signifikantné výsledky preukázali závislost' medzi prevalenciou osteoporózy a vekom v menopauze a prevalenciou osteoporózy a postupujúcim vekom v postmenopauze. Názory na vplyv BMI ako protektívneho, resp. rizikového faktora sa rôznia. Významný vplyv na hustotu kostných minerálov u žien po menopauze môžu mat́ niektoré behaviorálne faktory, ktoré sú preventabilné. Z výsledkov viacerých štúdií vyplýva súvislost' medzi prevalenciou osteoporózy fajčenia a konzumácie alkoholu.

Záver: Menopauza je kritickým obdobím pre zdravie kostí. Zvyšujúcim sa vekom žien v postmenopauzálnom období sa výskyt osteoporózy zvyšuje. V rámci prevencie sa odporúča vhodný druh stravovania, vystavenie sa slnečnému žiareniu, pravidelné cvičenie a pohyb a ukončit fajčenie a konzumáciu alkoholu.

Kl'účové slová: BMI; menopauza; osteoporóza; vek; životospráva

\section{References}

1. Aghaei M, Afshan HRB, Qorbani M, Dashti HS, Safari R (2013). Bone mineral density in Iranian patients: Effects of age, sex, and body mass index. Open J Prev Med 3(1): 128-131. DOI: 10.4236/ojpm.2013.31016.

2. Agrawal T, Verma AK (2013). Cross sectional study of osteoporosis among women. Med J Armed Forces India 69(2): 168-171. DOI: 10.1016/j.mjafi.2012.07.024.

3. Baccaro LF, Conde DM, Costa-Paiva L, Pinto-Neto AM (2015). The epidemiology and management of postmenopausal osteoporosis: a viewpoint from Brazil. Clin Interv Aging 10: 583-591. DOI: 10.2147/CIA.S54614.

4. Bijelic R, Milicevic S, Balaban J (2017). Risk Factors for Osteoporosis in Postmenopausal Women. Med Arch 71(1): 25-28. DOI: 10.5455/medarh.2017.71.25-28.

5. Binu AJ, Cherian KE, Kapoor N, Jebasingh FK, Asha HS, Paul TV (2019). Bone Health after Fifth Decade in Rural Ambulatory South Indian Postmenopausal Women. Indian J Community Med 44(3): 205-208. DOI: 10.4103/ijcm. IJCM_161_18.

6. Brown JP, Albert C, Nassar BA, Adachi JD, Cole D, Davison KS, et al. (2009). Bone turnover markers in the management of postmenopausal osteoporosis. Clin Biochem 42(10-11): 929-942. DOI: 10.1016/j.clinbiochem.2009.04.001.

7. Cunha-Henriques S, Costa-Paiva L, Pinto-Neto AM, FonsechiCarvesan G, Nanni L, Morais SS (2011). Postmenopausal women with osteoporosis and musculoskeletal status: a comparative cross-sectional study. J Clin Med Res 3(4): 168-176. DOI: 10.4021/jocmr537w.

8. Demirbag D, Ozdemir F, Ture M (2006). Effects of coffee consumption and smoking habit on bone mineral density. Rheumatol Int 26(6): 530-535. DOI: 10.1007/s00296-0050020-4.

9. Guiming Y, Huang Y, Cao H, Wu J, Jiang N, Cao X (2019). Association of breastfeeding and postmenopausal osteoporosis in Chinese women: a community-based retrospective study. BMC Womens Health 19(1): 110. DOI: 10.1186/s12905-0190808-0.

10. Haluzíková J (2017). Kvalita života u nemocných s hypertenzí. Logos Polytechnikos 8(1): 34-45.
11. Hamdi Kara I, Aydin S, Gemalmaz A, Aktürk Z, Yaman H, Bozdemir N, et al. (2008). Habitual tea drinking and bone mineral density in postmenopausal Turkish women: investigation of prevalence of postmenopausal osteoporosis in Turkey (IPPOT Study). Int J Vitam Nutr Res 77(6): 389-397. DOI: 10.1024/0300-9831.77.6.389 [published correction appears in Int J Vitam Nutr Res 78(3): 166].

12. Kalem MN, Kalem Z, Akgun N, Bakırarar B (2017). The relationship between postmenopausal women's sclerostin levels and their bone density, age, body mass index, hormonal status, and smoking and consumption of coffee and dairy products. Arch Gynecol Obstet 295(3): 785-793. DOI: 10.1007/s00404017-4288-x.

13. Karlamangla AS, Burnett-Bowie SAM, Crandall CJ (2018). Bone Health During the Menopause Transition and Beyond. Obstet Gynecol Clin North Am 45(4): 695-708. DOI: 10.1016/j. ogc.2018.07.012.

14. Kok HS, van Asselt KM, van der Schouw YT, Peeters PHM, Wijmenga C (2005). Genetic studies to identify genes underlying menopausal age. Hum Reprod Update 11(5): 483-493. DOI: 10.1093/humupd/dmi024.

15. Koothirezhi R, Ranganathan S (2021). Postmenopausal Syndrome. In: StatPearls [Internet]. Treasure Island (FL): StatPearls Publishing. [online] [cit. 2021-01-22]. Available from: https://www.ncbi.nlm.nih.gov/books/NBK560840/

16. Moron FJ, Ruiz A, Galan JJ (2009). Genetic and genomic insights into age at natural menopause. Genome Med 1(8): 76. DOI: 10.1186/gm76.

17. Rizzoli R, Bischoff-Ferrari H, Dawson-Hughes B, Weaver C (2014). Nutrition and bone health in women after the menopause. Womens Health (Lond) 10(6): 599-608. DOI: 10.2217/whe.14.40.

18. Salamat MR, Salamat AH, Abedi I, Janghorbani M (2013). Relationship between weight, body mass index, and bone mineral density in men referred for dual-energy X-ray absorptiometry scan in Isfahan, Iran. J Osteoporos 2013: 205963. DOI: $10.1155 / 2013 / 205963$.

19. Schoenaker DAJM, Jackson CA, Rowlands JV, Mishra GD (2014). Socioeconomic position, lifestyle factors and age at natural menopause: a systematic review and meta-analyses of studies across six continents. Int J Epidemiol 43(5): 1542-1562. DOI: 10.1093/ije/dyu094. 
20. Tian LM, Yang RF, Wei LH, Liu J, Yang Y, Shao FF, et al. (2017). Prevalence of osteoporosis and related lifestyle and metabolic factors of postmenopausal women and elderly men: A cross-sectional study in Gansu province, Northwestern of China. Medicine (Baltimore) 43: e8294. DOI: 10.1097/ MD.0000000000008294.

21. Török-Oancea R, Bala M (2015). Body weight, BMI, and stature have a protective effecton bone mineral density in women with postmenopausal vertebral osteoporosis, whereas greater age at menarcheand years after menopause have a negative effect. Asian Biomed 9(1): 81-86. DOI: 10.5372/1905-7415.0901.372.

22. van Asselt KM, Kok HS, Putter H, Wijmenga $C$, Peeters $P H$, van der Schouw YT, et al. (2004). Linkage analysis of extremely discordant and concordant sibling pairs identifies quantitative trait loci influencing variation in human menopausal age. Am J Hum Genet 74(3): 444-453. DOI: 10.1086/382136.

23. Veiga Silva AC, da Rosa MI, Fernandes BS, Lumertz S, Diniz RM, dos Reis Damiani MEF (2015). Factors associated with osteopenia and osteoporosis in women undergoing bone mineral density test. Revista Brasileira de Reumatologia (English Edition) 55(3): 223-228. DOI: 10.1016/j. rbre.2014.08.011.

24. Voorhuis M, Onland-Moret NC, van der Schouw YT, Fauser BCJM, Broekmans FJ (2010). Human studies on genetics of the age at natural menopause: a systematic review. Hum Reprod Update 16(4): 364-377. DOI: 10.1093/humupd/ dmp055. 